\title{
Groundwater vulnerability to pollution mapping of Ranchi district using GIS
}

\author{
R. Krishna $\cdot$ J. Iqbal • A. K. Gorai • \\ G. Pathak $\cdot$ F. Tuluri $\cdot$ P. B. Tchounwou
}

Received: 30 January 2014/ Accepted: 22 April 2014/Published online: 17 May 2014

(C) The Author(s) 2014. This article is published with open access at Springerlink.com

\begin{abstract}
Groundwater pollution due to anthropogenic activities is one of the major environmental problems in urban and industrial areas. The present study demonstrates the integrated approach with GIS and DRASTIC model to derive a groundwater vulnerability to pollution map. The model considers the seven hydrogeological factors [Depth to water table $(D)$, net recharge $(R)$, aquifer media $(A)$, soil media $(S)$, topography or slope $(T)$, impact of vadose zone $(I)$ and hydraulic Conductivity $(C)$ ] for generating the groundwater vulnerability to pollution map. The model was applied for assessing the groundwater vulnerability to pollution in Ranchi district, Jharkhand, India. The model was validated by comparing the model output (vulnerability indices) with the observed nitrate concentrations in groundwater in the study area. The reason behind the selection of nitrate is that the major sources of nitrate in groundwater are anthropogenic in nature. Groundwater samples were collected from 30 wells/tube wells distributed in the study area. The samples were analyzed in the laboratory for measuring the nitrate concentrations in groundwater. A sensitivity analysis of the integrated model was performed to evaluate the influence of single parameters on groundwater vulnerability index. New weights
\end{abstract}

R. Krishna · J. Iqbal · A. K. Gorai $(\bowtie) \cdot$ G. Pathak

Environmental Science and Engineering Group, Birla Institute of

Technology Mesra, Ranchi 835215, India

e-mail: amit_gorai@yahoo.co.uk

F. Tuluri

Department of Technology, Jackson State University, Jackson, MS 39217, USA

P. B. Tchounwou

Department of Biology, Jackson State University, Jackson, MS 39217, USA were computed for each input parameters to understand the influence of individual hydrogeological factors in vulnerability indices in the study area. Aquifer vulnerability maps generated in this study can be used for environmental planning and groundwater management.

Keywords Groundwater vulnerability - Ranchi .

DRASTIC · Sensitivity analysis · GIS

\section{Introduction}

Groundwater is the most important water resource on earth (Villeneuve et al. 1990). Groundwater quality is under considerable threat of contamination especially in agriculture-dominated areas due to intense use of fertilizers and pesticides (Giambelluca et al. 1996; Soutter and Musy 1998; Lake et al. 2003; Thapinta and Hudak 2003; Chae et al. 2004). Thus, the protection of groundwater against anthropogenic pollution is of crucial importance (Zektser et al. 2004). Assessment of groundwater vulnerability to pollution helps to determine the proneness of groundwater contamination and hence essential for managing and preserving the groundwater quality (Fobe and Goossens 1990; Worrall et al. 2002; Worrall and Besien 2004).

Groundwater vulnerability to pollution studies helps to categorize the land on the basis of its proneness to vulnerability (Gogu and Dassargues 2000a). That is, groundwater vulnerability assessment delineates areas that are more susceptible to contamination on the basis of the different hydrogeological factors and anthropogenic sources. In general, the study explains the estimation of the contaminants migration potential from land surface to groundwater through the unsaturated zones (Connell and 


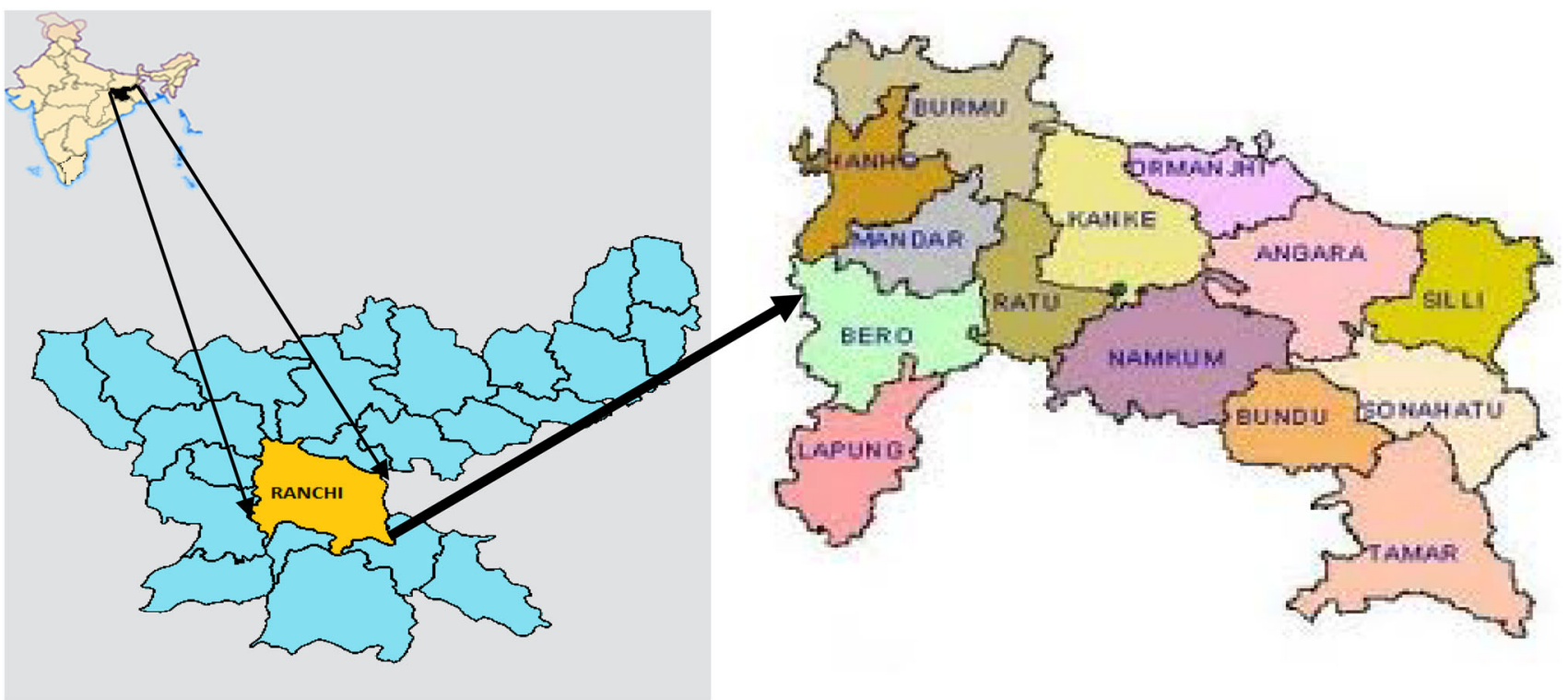

Fig. 1 Study area map

Fig. 2 Flow chart of the working methodology

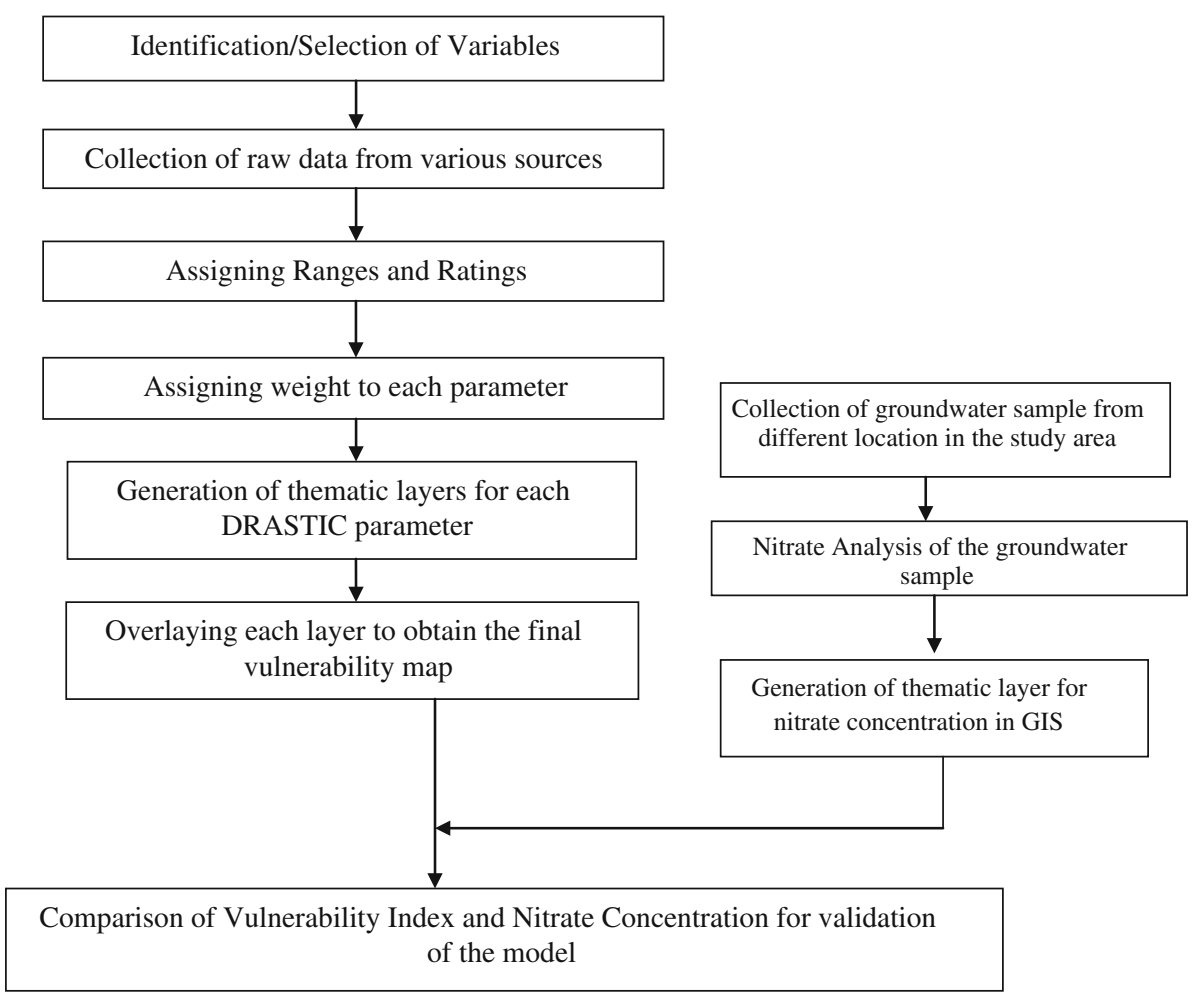

Daele 2003). Groundwater vulnerability assessment is essential for management of groundwater resources and subsequent land use planning (Rupert 2001; Babiker et al. 2005). Groundwater vulnerability maps provide visual information for more vulnerable zones which help to protect groundwater resources and also to evaluate the potential for water quality improvement by changing the agricultural practices and land use applications (Connell and Daele 2003; Rupert 2001; Babiker et al. 2005; Burkart and Feher 1996).

Groundwater vulnerability assessment can be used in planning, policy analysis, and decision making, viz., advising decision makers for adopting specific management options to mitigate the quality of groundwater 
Table 1 Ranges and ratings for various hydrogeological settings (Aller et al. 1987)

\begin{tabular}{|c|c|c|c|c|c|}
\hline \multicolumn{3}{|l|}{ Depth to groundwater } & \multicolumn{3}{|l|}{ Net recharge } \\
\hline Ranges (m) & Ratings $\left(D_{\mathrm{r}}\right)$ & Sub-index $\left(D_{\mathrm{r}} \times D_{\mathrm{w}}\right)$ & Ranges $(\mathrm{cm})$ & $\begin{array}{l}\text { Ratings } \\
\left(R_{\mathrm{r}}\right)\end{array}$ & $\begin{array}{l}\text { Sub-index } \\
\left(R_{\mathrm{r}} \times R_{\mathrm{w}}\right)\end{array}$ \\
\hline $0-1.52$ & 10 & 50 & $0-5.08$ & 1 & 4 \\
\hline $1.52-4.57$ & 9 & 45 & $5.08-10.16$ & 3 & 12 \\
\hline $4.57-9.14$ & 7 & 35 & $10.16-17.78$ & 6 & 24 \\
\hline $9.14-15.24$ & 5 & 25 & $17.78-25.4$ & 8 & 32 \\
\hline $15.24-22.86$ & 3 & 15 & $25.4+$ & 9 & 36 \\
\hline $22.86-30.48$ & 2 & 10 & & & \\
\hline $30.48+$ & 1 & 5 & & & \\
\hline Weight $\left(D_{\mathrm{w}}\right)$ & 5 & & Weight $\left(R_{\mathrm{w}}\right)$ & 4 & \\
\hline Aquifer type & & & Soil type & & \\
\hline Type & $\begin{array}{l}\text { Ratings } \\
\quad\left(A_{\mathrm{r}}\right)\end{array}$ & $\begin{array}{l}\text { Sub-index } \\
\qquad\left(A_{\mathrm{r}} \times A_{\mathrm{w}}\right)\end{array}$ & Type & $\begin{array}{l}\text { Ratings } \\
\qquad\left(S_{\mathrm{r}}\right)\end{array}$ & $\begin{array}{l}\text { Sub-index } \\
\quad\left(S_{\mathrm{r}} \times S_{\mathrm{w}}\right)\end{array}$ \\
\hline Massive shale & 2 & 6 & Thin or absent & 10 & 20 \\
\hline Metamorphic/igneous & 3 & 9 & Gravel & 10 & 20 \\
\hline Weathered metamorphic/igneous & 4 & 12 & Sand & 9 & 18 \\
\hline Glacial till & 5 & 15 & Peat & 8 & 16 \\
\hline $\begin{array}{l}\text { Bedded sandstone, limestone and } \\
\text { shale sequences }\end{array}$ & 6 & 18 & Shrinking and/or aggregated clay & 7 & 14 \\
\hline Massive sandstone & 6 & 18 & Sandy loam & 6 & 12 \\
\hline Massive limestone & 6 & 18 & Loam & 5 & 10 \\
\hline Sand and gravel & 8 & 24 & Silty loam & 4 & 08 \\
\hline Basalt & 9 & 27 & Clay loam & 3 & 06 \\
\hline Karst limestone & 10 & 30 & Muck & 2 & 04 \\
\hline Weight $\left(A_{\mathrm{w}}\right)$ & 3 & & Non-shrinking and non-aggregated clay & 1 & 02 \\
\hline Topography or slope & & & Weight $\left(S_{\mathrm{w}}\right)$ & 2 & \\
\hline Ranges (in \%) & $\begin{array}{l}\text { Ratings } \\
\left(T_{\mathrm{r}}\right)\end{array}$ & $\begin{array}{l}\text { Sub-index } \\
\quad\left(T_{\mathrm{r}} \times T_{\mathrm{w}}\right)\end{array}$ & Impact of vadose zone & & \\
\hline $0-2$ & 10 & 10 & Type & $\begin{array}{l}\text { Ratings } \\
\left(I_{\mathrm{r}}\right)\end{array}$ & $\begin{array}{r}\text { Sub-index } \\
\left(I_{\mathrm{r}} \times I_{\mathrm{w}}\right)\end{array}$ \\
\hline $2-6$ & 9 & 9 & Confining layer & 1 & 5 \\
\hline $6-12$ & 5 & 5 & Silt/clay & 3 & 15 \\
\hline $12-18$ & 3 & 3 & Shale & 3 & 15 \\
\hline $18+$ & 1 & 1 & Limestone & 6 & 30 \\
\hline Weight $\left(T_{\mathrm{w}}\right)$ & 1 & & Sandstone & 6 & 30 \\
\hline Hydraulic conductivity & & & Bedded limestone, sandstone, shale & 6 & 30 \\
\hline Range (m/d) & $\begin{array}{l}\text { Ratings } \\
\qquad\left(C_{\mathrm{r}}\right)\end{array}$ & $\begin{array}{l}\text { Sub-index } \\
\qquad\left(C_{\mathrm{w}} \times C_{\mathrm{r}}\right)\end{array}$ & $\begin{array}{l}\text { Sand and gravel with significant } \\
\text { silt and clay }\end{array}$ & 6 & 30 \\
\hline $0.04-4.07$ & 1 & 3 & Metamorphic/igneous & 4 & 20 \\
\hline $4.07-12.22$ & 2 & 06 & Sand and gravel & 8 & 40 \\
\hline $12.22-28.52$ & 4 & 12 & Basalt & 9 & 45 \\
\hline $28.52-40.74$ & 6 & 18 & Karst limestone & 10 & 50 \\
\hline $40.74-81.49$ & 8 & 24 & & & \\
\hline $81.49+$ & 10 & 30 & & & \\
\hline Weight $\left(C_{\mathrm{w}}\right)$ & 3 & & Weight $\left(I_{\mathrm{w}}\right)$ & 5 & \\
\hline
\end{tabular}

resources; demonstrating the implications and consequences of their decisions; providing direction for using groundwater resources; highlighting about proper land use practices and activities; and educating the general public regarding the consequences of groundwater contamination (NRC 1993). 
Table 2 Data types and its sources for creation of output layers

\begin{tabular}{llll}
\hline $\begin{array}{l}\text { S1. } \\
\text { No. }\end{array}$ & Data types & Sources & Output layer \\
\hline 1 & Well data & $\begin{array}{c}\text { Real time observation using } \\
\text { GPS and tape }\end{array}$ & Depth to water \\
2 & $\begin{array}{c}\text { Average annual } \\
\text { rainfall }\end{array}$ & $\begin{array}{c}\text { Indian Meteorological } \\
\text { Department, India }\end{array}$ & Net recharge \\
3 & Geologic map & $\begin{array}{c}\text { Central Ground Water } \\
\text { Board, PATNA }\end{array}$ & Aquifer media \\
4 & Soil map & $\begin{array}{c}\text { Birsa Agricultural } \\
\text { University, RANCHI }\end{array}$ & Soil media \\
5 & SRTM data & $\begin{array}{c}\text { USGS GLOVIS } \\
\text { visualization viewer }\end{array}$ & Topography \\
6 & Soil map & $\begin{array}{c}\text { Birsa Agricultural } \\
\text { University, RANCHI }\end{array}$ & $\begin{array}{c}\text { Impact of } \\
\text { vadose zone }\end{array}$ \\
7 & Geologic map & $\begin{array}{c}\text { Central Ground Water } \\
\text { Board, PATNA }\end{array}$ & $\begin{array}{c}\text { Hydraulic } \\
\text { conductivity }\end{array}$ \\
\hline
\end{tabular}

The concept of aquifer vulnerability to external pollution was introduced in 1960s by (Margat 1968), with several systems of aquifer vulnerability assessment developed in the following years (Aller et al. 1987; Civita 1994; Vrba and Zaporozec 1994; Sinan and Razack 2009; Polemio et al. 2009; Foster 1987). They found that the reason behind the different vulnerabilities is the different hydrogeological settings. Many approaches have been developed to evaluate aquifer vulnerability. These are overlay/index methods, process-based methods and statistical methods (Zhang et al. 1996; Tesoriero et al. 1998). The overlay/index methods use location-specific vulnerability indices based on the hydrogeological factors controlling movement of pollutants from the land surface to the water bearing strata. The process-based methods use contaminants transport models to estimate the contaminant migration (Barbash and Resek 1996). Statistical methods estimate the associations between the spatial variables and the occurrence of pollutants in the groundwater using various statistics.

Among all the approaches mentioned above, the overlay and index method has been the most widely adopted approach for wide-scale groundwater vulnerability assessments. Scientist started giving predictions of groundwater pollution potential based on hydrogeological settings (Polemio et al. 2009; Almasri Mohammad 2008; Berkhoff 2008; Rahman 2008; Massone et al. 2010; Kwansiririkul et al. 2004; Kim and Hamm 1999; Secunda et al. 1998; Vias et al. 2005; Brosig Karolin et al. 2008; Ferreira Lobo and Oliveira Manuel 2004; Nouri and Malmasi 2005; Herlinger and Viero 2007; Shirazi et al. 2012, 2013; Neshat Aminreza et al. 2014). This paper aims to demonstrate a GIS-based DRASTIC model for groundwater vulnerability assessment of Ranchi district. The validation of the model prediction was done on the basis of observed nitrate concentration in groundwater in the study area. Sensitivity analysis of the model was also carried out to understand the influence of the individual input variables on groundwater vulnerability to pollution index.

\section{Study area}

The area selected for the proposed study is Ranchi district. Ranchi district lies in the southern part of Jharkhand state and bounded by other district of Jharkhand, viz., Hazaribagh, West Singhbhum, Gumla, Lohardaga, and East Singhbhum. This is also bounded by Purulia district of West Bengal. The district has a total area of $4,912 \mathrm{~km}^{2}$ and is located between $22^{\circ} 45^{\prime}-23^{\circ} 45^{\prime}$ North latitude to $84^{\circ} 45^{\prime}-$ $84^{\circ} 50^{\prime}$ East longitude. The district comprises of 14 blocks namely Ormanjhi, Kanke, Ratu, Bero, Burmu, Lapung, Chanho, Mandar, Bundu, Tamar, Angara, Sonahatu, Silli, Namkum as shown in Fig. 1.

The climate of Ranchi district is a subtropical climate. This is characterized by hot summer season from March to May and well-distributed rainfall during southwest monsoon season from June to October. Ranchi district has varied hydrogeological characteristics and hence the groundwater potential differs from one location to another. The three-fourth of the district area is underlain by Chotanagpur granite gneiss of preCambrian age (CGWB 2009). In two blocks (Ratu and Bero) thick lateritic capping is placed above granite gneiss. A big patch of older alluvium exists in Mandar block and limestone rock exists in northernmost portion of Burmu block. The northernmost and southernmost parts of the district are mainly covered with hillocks and forests. In general, the altitude of the area varies from 500 to $700 \mathrm{~m}$ above mean sea level, but there are many hillocks through the district having altitude more than $700 \mathrm{~m}$ above mean sea level. Two types of aquifers (Weathered aquifer and fractured aquifers) exist in the study area. Thickness of weathered aquifers varies from 10 to $25 \mathrm{~m}$ in granite terrain and 30 to $60 \mathrm{~m}$ in lateritic terrain. In weathered aquifers groundwater occurs in unconfined condition, while in fractured aquifer groundwater occurs in semiconfined to confined conditions.

\section{Materials and methods}

Groundwater vulnerability was evaluated using hydrogeological factors that can influence the pollutant transport through the vadose zone to the water bearing strata using GIS-based DRASTIC (Aller et al. 1987) method. The flowchart (shown in Fig. 2) represents the general overview of the research methodology. In the present study, seven hydrogeological parameters [Depth to water table $(D)$, net recharge $(R)$, aquifer media $(A)$, soil media $(S)$, 


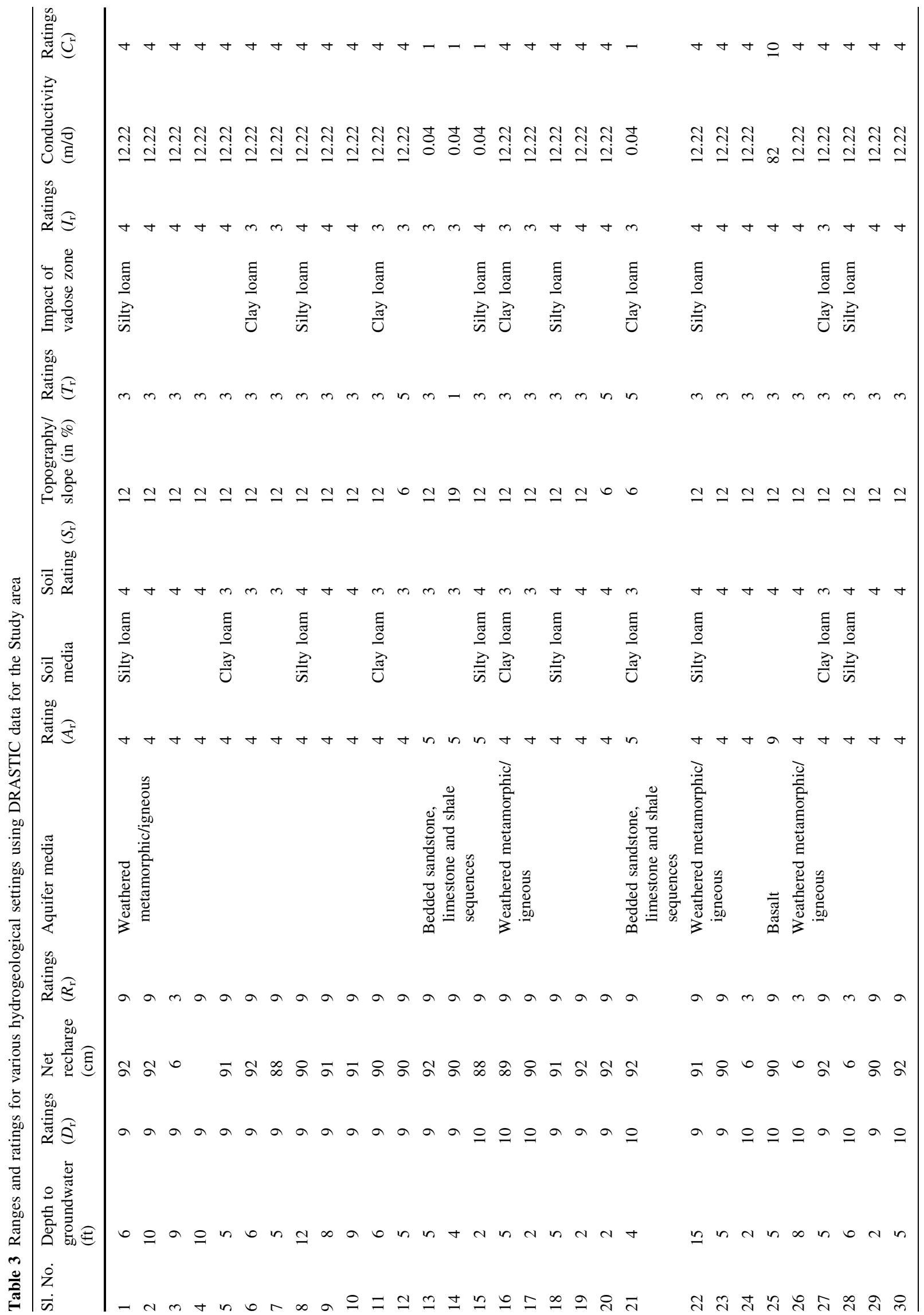


topography $(T)$, impact of vadose zone $(I)$ and hydraulic Conductivity $(C)$ ] were considered for assessing the groundwater vulnerability.

Thematic maps of seven factors $(D, R, A, S, T, I$, and $C)$ were generated and used for producing the final groundwater vulnerability to pollution index map. The thematic values in each of the seven hydrogeological maps were classified into corresponding ranges as per the DRASTIC model. Each range was assigned their corresponding ratings as per the DRASTIC model. Weight multipliers were then used for each factor to balance and enhance its importance. The final vulnerability map was computed as the weighted sum overlay of the seven layers using Eq. (1) and was termed as DRASTIC INDEX (DI).

$$
\begin{aligned}
\text { DRASTIC.INDEX (DI) }= & D_{\mathrm{r}} D_{\mathrm{w}}+R_{\mathrm{r}} R_{\mathrm{w}}+A_{\mathrm{r}} A_{\mathrm{w}}+S_{\mathrm{r}} S_{\mathrm{w}} \\
& +T_{\mathrm{r}} T_{\mathrm{w}}+I_{\mathrm{r}} I_{\mathrm{w}}+C_{\mathrm{r}} C_{\mathrm{w}}
\end{aligned}
$$

where, $D_{\mathrm{r}}, R_{\mathrm{r}}, A_{\mathrm{r}}, S_{\mathrm{r}}, T_{\mathrm{r}}, I_{\mathrm{r}}$, and $C_{\mathrm{r}}$ are ratings assigned to depth to water table, net recharge, aquifer media, soil media, topography or slope, impact of vadose zone, and hydraulic conductivity, respectively.

$D_{\mathrm{w}}, R_{\mathrm{w}}, A_{\mathrm{w}}, S_{\mathrm{w}}, T_{\mathrm{w}}, I_{\mathrm{w}}$, and $C_{\mathrm{w}}$ are weights assigned to depth to water table, net recharge, aquifer media, soil media, topography or slope, impact of vadose zone, and hydraulic conductivity, respectively.

Every parameter in the model assigned a fixed weight (listed in Table 1) indicating the relative influence of the parameter in transporting contaminants to the groundwater. Each input factor has been divided into either ranges or significant media types that affect groundwater vulnerability. The media types such as aquifer material, soil type and impact of vadose zone, cannot be measured numerically and hence ratings were assigned to each type of media. Each range of each DRASTIC parameter has been evaluated with respect to the others to determine its relative significance to pollution potential, and has been assigned a rating of 1-10. The "easiest to be polluted" was assigned a rating ten, except net recharge (which is 9) and the "most difficult to pollute" was assigned a rating of one. The numerical ratings, which were established using the Delphi technique (Aller et al. 1987), are well defined and have been used worldwide (Al-Adamat et al. 2003; Anwar et al. 2003; Chandrashekhar et al. 1999; Dixon 2005). The ratings for each parameter are listed in Table 1 for all the ranges and types.

\section{Data sources and generation of thematic layers}

The raw data were collected or derived from various published reports/maps for the generation of the thematic layers and are listed in Table 2. Thematic layers for each hydrogeological parameter were generated using ArcGIS software version 9.3 .
Fig. 3 a Depth to groundwater, b1 rainfall map, b2 land use map, b net recharge, $\mathbf{c}$ aquifer media, $\mathbf{d}$ soil media, $\mathbf{e}$ topography, $\mathbf{f}$ impact of vadose zone, $\mathbf{g}$ hydraulic Conductivity

Depth to groundwater

The depth to groundwater table parameter was derived from water level data collected from Central Ground Water Board (CGWB), Ranchi. The depth to groundwater table is shallow and has a range of $2-15 \mathrm{ft}$ below ground level. The well data were then used to generate the map for depth to water table contoured by interpolating using inverse distance weighted (IDW) method. The study area was extracted using the district boundary as a mask. The thematic map was reclassified into two classes, corresponds to the DRASTIC model range value (listed in Table 1). Though, the ranges defined for different classes (in Table 1) are in meter, these values were converted into feet during rating assignment. The depth to water table values and their corresponding ratings are shown in Table 3. The map generated for depth to water is shown in Fig. 3a.

Net recharge

The thematic map of precipitation was generated using the rainfall data collected from Indian Meteorological Division (IMD), India as shown in Fig. 3b1. The evapotranspiration map was derived from precipitation map by assuming the rate of evapotranspiration to be $5 \%$ of the precipitation (value taken from a report of IMD, Ranchi). The land use map of the study area was prepared and reclassified into five categories as agricultural land, built-up area, forest area, waste land and water bodies. The runoff coefficient assigned to different categories ranges from 0 to 1 depending on the land use type as shown in Fig. 3b2. The values were selected on the basis of rational formula for runoff coefficient (Source: http://water.me.vccs.edu/courses/ CIV246/table2b.htm).

The net recharge map was derived in GIS using the formula as

$$
\begin{aligned}
\text { net recharge }= & \text { precipitation }(\text { rainfall })-0.05 \\
& \times \text { precipitation }(\text { rainfall }) \\
& - \text { precipitation }(\text { rainfall }) \\
& \times \text { run off coefficients }
\end{aligned}
$$

The net recharge in the thematic map was reclassified into two types and assigned their corresponding ratings. The map layer for net recharge is shown in Fig. 3(b).

\section{Aquifer media}

Aquifer media map was prepared from the geologic map of Ranchi district. Aquifer media in the study area 

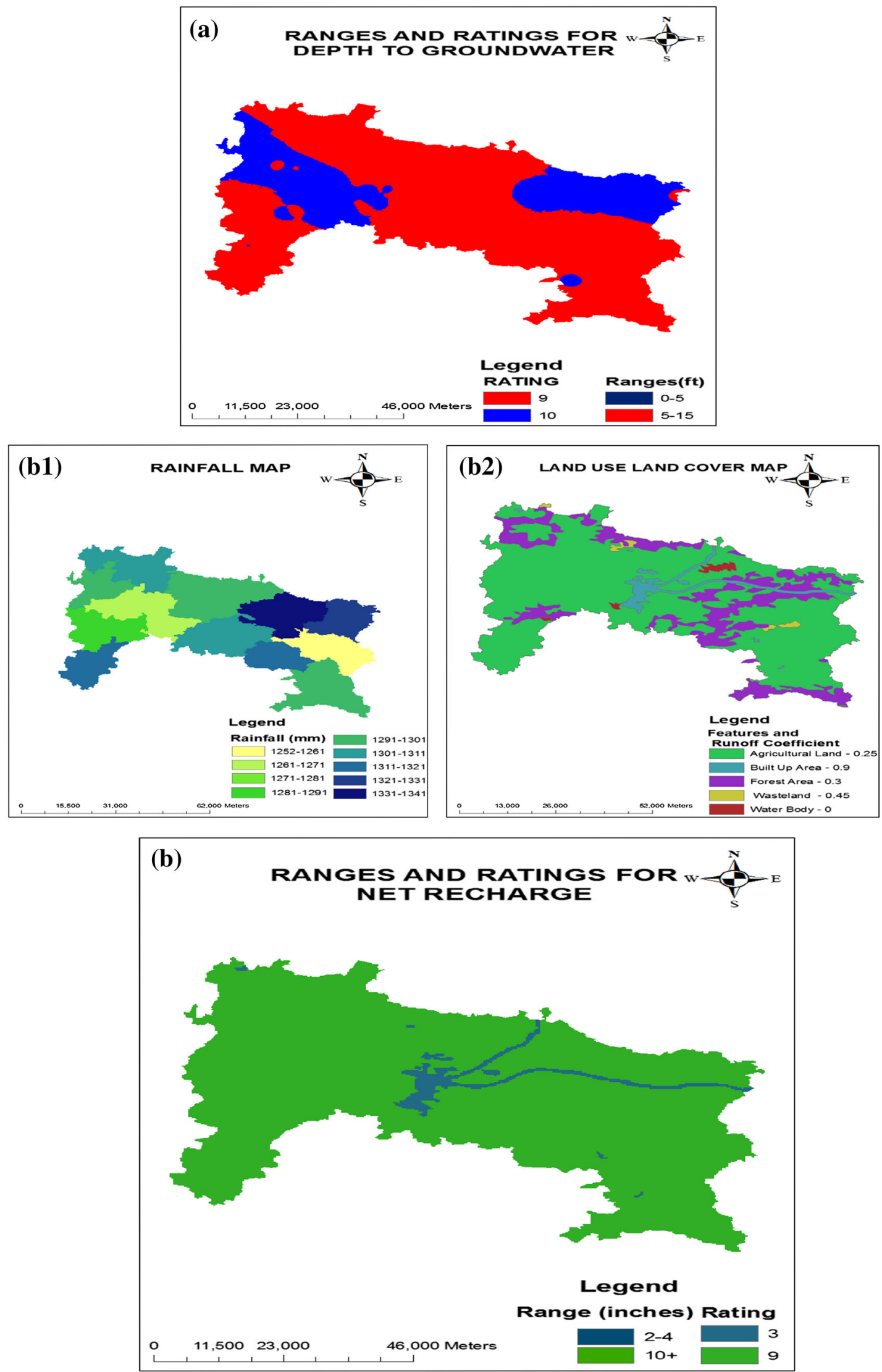
(c) RANGES AND RATINGS FOR AQUIFER MEDIA

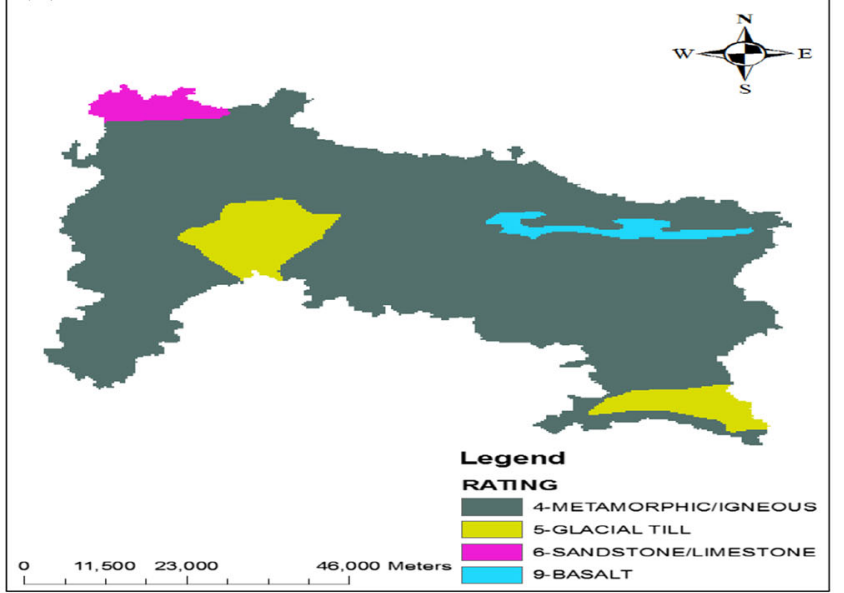

(e)

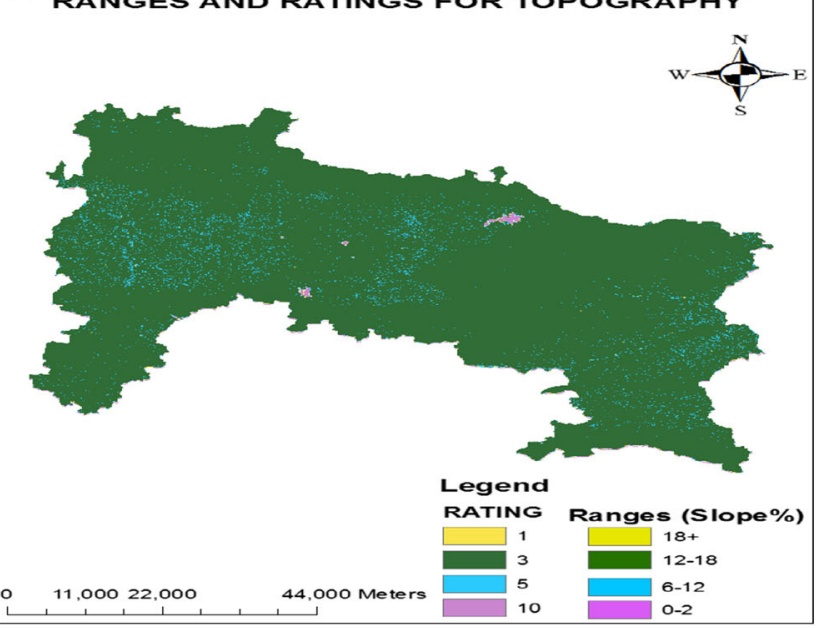

(g)

RATINGS FOR HYDRAULIC CONDUCTIVITY

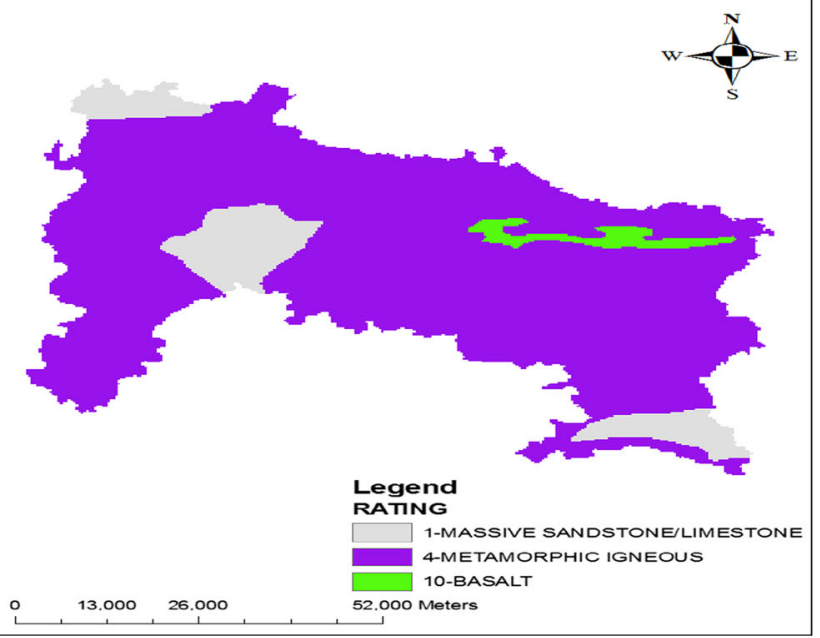

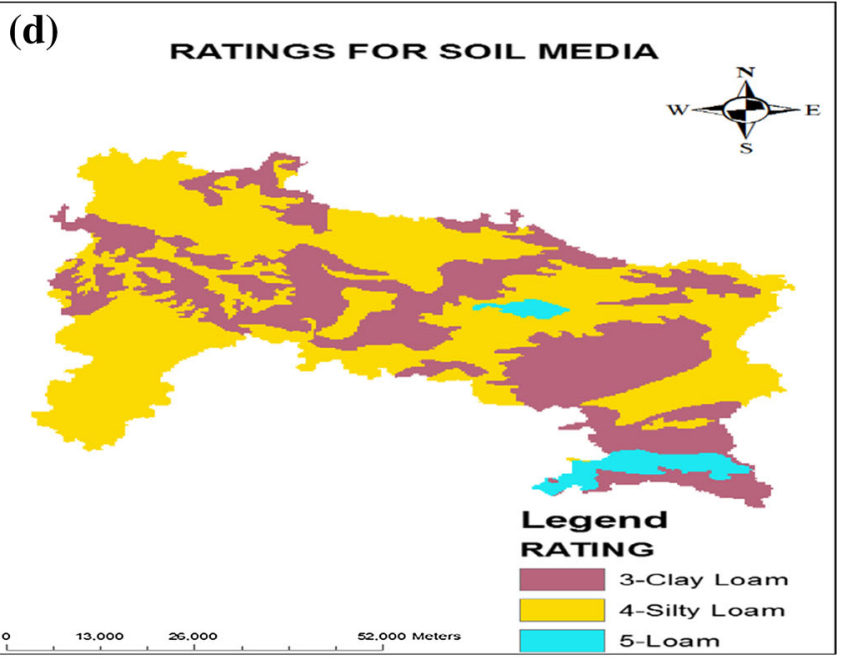

(f) RATINGS FOR IMPACT OF VADOSE ZONE

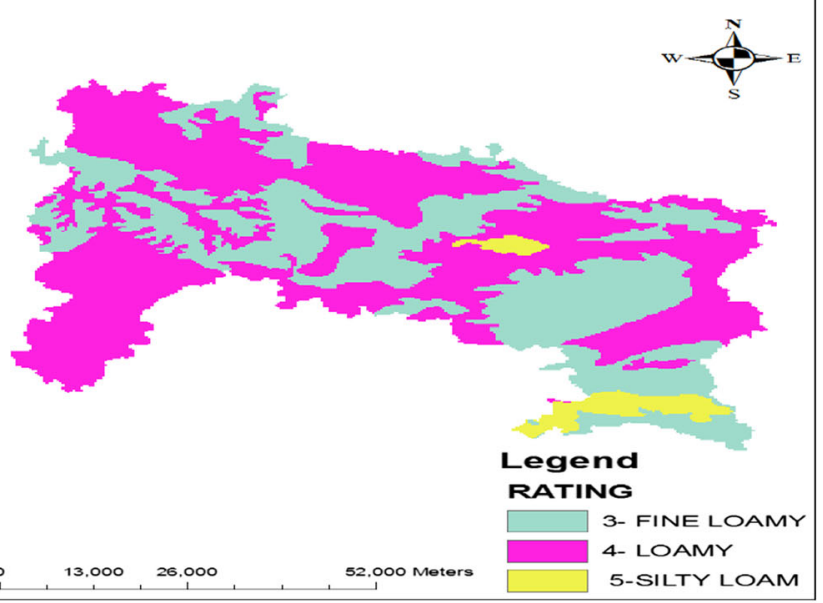

Fig. 3 continued 
Fig. 4 Relative potential of groundwater vulnerability to pollution map

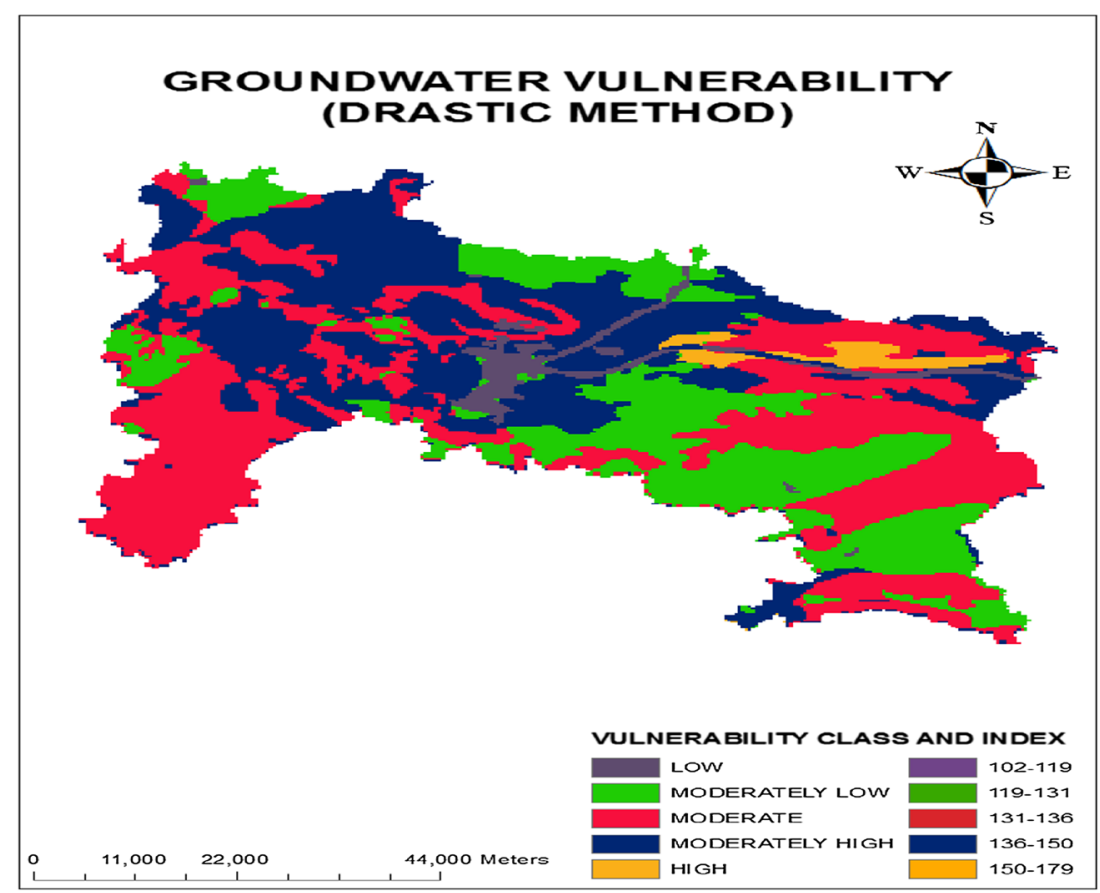

were reclassified into four types and their corresponding ratings were assigned for each aquifer media as given in Table 3. The thematic map is shown in Fig. 3c.

Soil media

Soil media map was prepared from the soil map of Ranchi district. The soil profile was collected from Birsa Agriculture University (BAU), Ranchi. It was digitized in ArcGIS for generating the thematic map of soil media. The study area consists of fine to coarse loamy-type soil. The soil type was classified into three types and their corresponding ratings were assigned for each type of soil media. The map generated for soil media is shown in Fig. 3d.

\section{Topography}

The topography map was prepared using the shuttle radar topography mission (SRTM) data. The percentage slope raster file was created from Digital Elevation Model (DEM) using spatial analyst. The slope percentage in the study area was reclassified into four classes and assigned their corresponding ratings as given in Table 3 . The thematic map layer of topography is shown in Fig. 3e.

Impact of vadose zone

Due to unavailability of vadose zone data in the study area, information of the soil media was used to derive the approximate ratings for Vadose zone. The map was converted to a raster data by defining ratings for the vadose zone media (using soil media data) (Table 3; Fig. 3d). The thematic map of the impact of vadose zone is shown in Fig. 3f.

Hydraulic conductivity

Due to unavailability of hydraulic conductivity data in the study area, information of the aquifer media was used to derive the approximate ratings for hydraulic conductivity. It was converted to raster data according to the defined ratings. The ratings of the hydraulic conductivity were assigned (using aquifer media data instead here) as per Table 3. The map of hydraulic conductivity is shown in Fig. 3g.

\section{Results and discussion}

The GIS-based DRASTIC model was developed for generating the aquifer vulnerability map of Ranchi District. This will reflect the aquifer's inherent capacity to become contaminated. The final map represents the range of the vulnerability indices. The higher the vulnerability index, the higher is the capacity of the hydrogeologic condition to readily move contaminants from surface to the groundwater. On the other hand, low indices represent groundwater is better protected from contaminant leaching by the natural environment. The final vulnerability map was obtained by overlaying the seven hydrogeological thematic layers in ArcGIS software version 9.3. The final groundwater vulnerability map is shown in Fig. 4. The range of the vulnerability indices was reclassified into five classes 
(low, moderately low, moderate, moderately high, and high) on the basis of Jenks natural breaks that describe the relative probability of contamination of the groundwater resources. A regional scale has been used for comparing the relative vulnerability of groundwater resources.

The result of groundwater vulnerability to pollution assessment indicates that the index value ranged from 102 to 179 . The maximum and minimum vulnerability indices were calculated by the sum of the product of maximum and minimum ratings for all the parameters with its corresponding weightage, respectively. The study area was divided into five zones of relative vulnerability: low groundwater vulnerability risk zone (index: 102-119); moderately low vulnerability risk zone (index: 119-131), moderate vulnerability zone (index: 131-136), moderately high vulnerability zone (index: 136-150), and high vulnerability zone (index: 150-179).

The results reveal that the percentage of total area under different vulnerability classes is $3.45 \%\left(168.13 \mathrm{~km}^{2}\right)$, $22.12 \% \quad\left(1,075.45 \mathrm{~km}^{2}\right), \quad 38.85 \% \quad\left(1,890.99 \mathrm{~km}^{2}\right)$, $33.63 \%\left(1,636.96 \mathrm{~km}^{2}\right)$, and $1.85 \%\left(94.97 \mathrm{~km}^{2}\right)$ for low, moderately low, moderate, moderately high and high, respectively. The high vulnerability zones are mainly lie in the blocks of Sonahatu, Angara, and Silli.

$$
\begin{aligned}
& \text { maximum vulnerability index }=\sum_{i=1}^{7} \text { rating }_{i} \times \text { weightage }_{i} \\
& =10 \times 5+9 \times 4+10 \times 3+10 \times 1+10 \times 5+10 \times 3=226
\end{aligned}
$$

similarly,

minimum vulnerability index $=\sum_{i=1}^{7}$ rating $_{i} \times$ weightage $_{i}$

$=1 * 5+1 * 4+1 * 3+1 * 2+1 * 1+1 * 5+1 * 3=23$

Though, it is very difficult to say the role of a particular parameter on the spatial changes in the vulnerability index without sensitivity analysis. This is because variation in depth to groundwater table in the study area was found to be low. But the vulnerability map clearly reveals that the depth to groundwater has an insignificant role in spatial changes in vulnerability index. It is clear from the map that the vulnerability is low in the area having higher depth to groundwater and vice versa. Furthermore, the variation of net recharge was very high in the study area and hence had a high influence on the spatial changes in the vulnerability index. Thus, to understand the influence of each parameter sensitivity analysis was carried out. This is explained in sensitivity analysis section.

\section{Validation of the model}

The model was validated by comparing the model output (vulnerability index) with the observed nitrate concentration in groundwater in the study area. The reason behind the selection of nitrate was that the major sources of nitrate in groundwater are various anthropogenic activities like fertilizer used in the agricultural field. The DRASTIC model assumes that the contaminant has the mobility of water. Nitrate being completely soluble in water and hence very nearly satisfies this assumption. Groundwater samples were collected from 30 locations in the study area and analyzed in laboratory for measuring the nitrate concentrations. The spatial locations of the sampling points were recorded by a handheld GPS meter. Nitrate analysis was done as per the standard methods (APHA 1995) using UV-VIS spectrophotometer. In this method generally the absorption was measured twice, i.e., at $220 \mathrm{~nm}$ for nitrate concentration and at $275 \mathrm{~nm}$ for organic matters which cause hindrance. Then the absorption at $220 \mathrm{~nm}$ was subtracted from twice the absorption at $275 \mathrm{~nm}$ to obtain the actual nitrate concentration of a given water sample. Nitrate concentrations were found to be in the range of 10.12-51.34 mg/l. The DRASTIC indices of the corresponding points were determined from vulnerability index map (Fig. 4). Figure 5 clearly indicates that the trends of nitrate concentration and vulnerability indices were matched closely in most of the occasions except a few. The correlation between the vulnerability indices and observed nitrate concentration was found to be 0.859 .

This clearly indicates that the model can be accepted for vulnerability assessment and predict with 85.9 percent accuracy. The comparative values of observed nitrate concentration at 30 sampling locations were superimposed on the vulnerability index map as shown in Fig. 6. The range of observed nitrate concentration was classified into three levels ( $<30 \mathrm{mg} / \mathrm{l} ; 30-45 \mathrm{mg} / \mathrm{l}$; and $>45 \mathrm{mg} / \mathrm{l})$ and compared with the corresponding vulnerability indices. Figure 6 clearly indicates that nitrate concentrations of the samples lie down in level $1(<30 \mathrm{mg} / \mathrm{l})$ were mainly stretched out in the class of moderately low or moderate vulnerability class. Similarly, the nitrate concentration of the samples which lies down in level $2(30-45 \mathrm{mg} / \mathrm{l})$ was mainly stretched out in the class of moderate or moderately high vulnerability class. It was observed that only one sample had the concentration level greater than $45 \mathrm{mg} / 1$ that is in level 3 and this location was stretched out in high vulnerability class. There were few samples that contradicted the law (high vulnerability class zone has high nitrate concentration) due to some other factors which were not defined in the model.

\section{Sensitivity analysis}

The ideas or views of scientists' conflict in regard to DRASTIC model for groundwater vulnerability to pollution assessment. Some scientists agreed that groundwater 
Fig. 5 Vulnerability index vs. nitrate concentration
Fig. 6 Vulnerability index and corresponding nitrate concentration
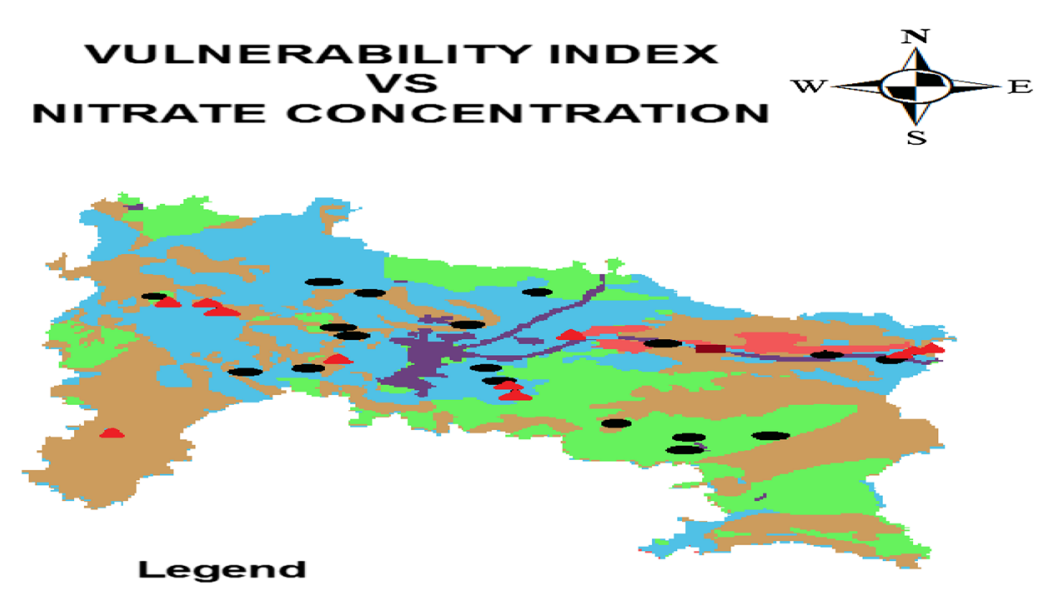

Legend

Vulnerability Index

102-119 LOW

119-131 MODERATELY LOW

131-136 MODERATE

136-150 MODERATELY HIGH

150-179 HIGH

4 Meters
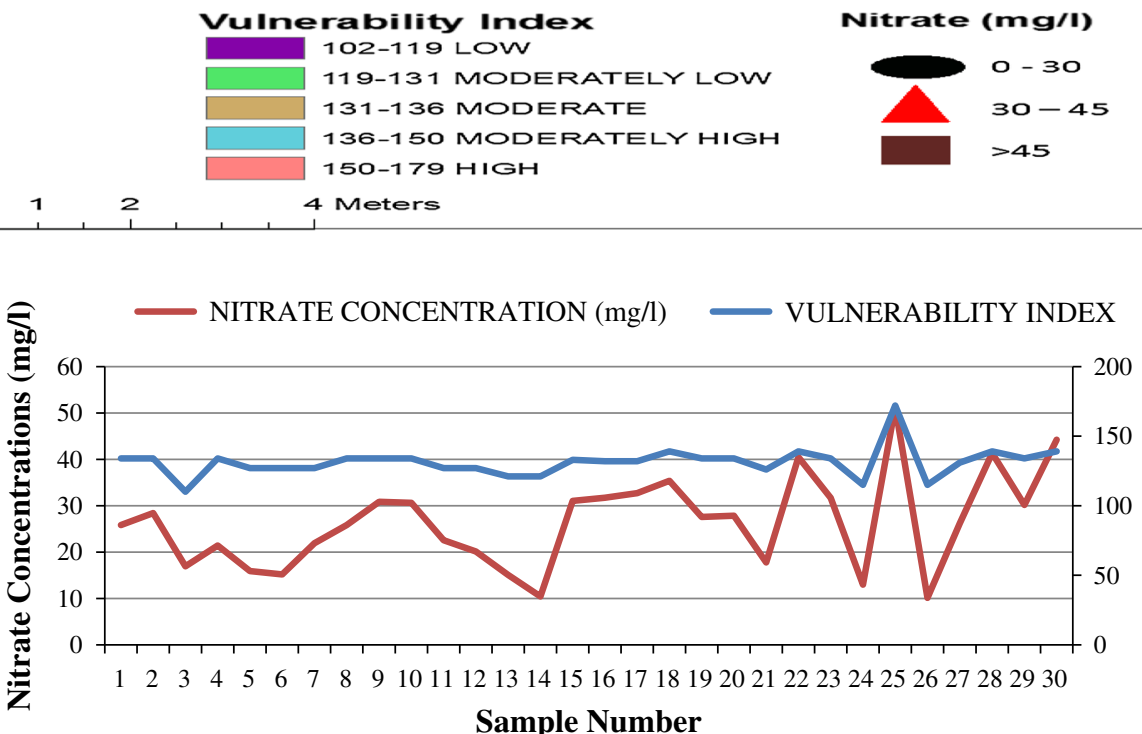

vulnerability assessment can be studied without considering all the factors of the DRASTIC model (Merchant 1994), while some others not agreed with the ideas (Napolitano and Fabbri 1996). To make a common consensus sensitivity analysis of the model and groundwater contamination analysis are carried out.

Sensitivity analysis provides information on the influence of rating and weights assigned to each of the factors considered in the model (Gogu and Dassargues 2000b). Lodwik et al. (1990) defined the measure of map removal sensitivity. This explains the degree of sensitivity associated with removing one or more map layers. The sensitivity analysis mentioned above can be measured by removing one or more layer maps using the following equation:

$S_{i}=\left|\frac{V_{i}}{N}-\frac{V_{x i}}{n}\right|$.

where, $S_{i}$ represents sensitivity for $i$ th sub-area associated with the removal of one map ( $x$-factor), $V_{i}$ is vulnerability index computed using Eq. (1) for the $i$ th sub-area, $V_{x i}$, vulnerability index computed for $i$ th sub-area excluding o map layer $(x), N$ is the number of map layers used to compute vulnerability index in Eq. (1) and $n$ is number of map layers used for sensitivity analysis. To assess the magnitude of the variation created by removal of one parameter, the variation index was computed as:

$\operatorname{Var}_{i}=\left(\frac{V_{i-V x_{i}}}{V_{\mathrm{i}}}\right) \times 100$

where, $\operatorname{Var}_{i}$ is variation index of the map removal parameter; and $V_{i}$ and $V_{x i}$ represent vulnerability index for the $i$ th sub-area in two different conditions as mentioned above. Variation index estimates the effect on vulnerability indices due to removal of each parameter. Its value can be either positive or negative, depending on vulnerability index. Variation index directly depends upon the weighting system.

The single parameter sensitivity test was carried out to estimate the role of each parameters considered in the model on the vulnerability measure. The objective of this 
analysis is to compare the real or "effective" weight of each parameter with that of the corresponding assigned or "theoretical", weight. The effective weight of a parameter in $i$ th sub-area can be determined using the following equation:

$W_{x i=}\left(\frac{X_{\mathrm{r} i \times X_{\mathrm{w} i}}}{V_{i}}\right) \times 100$

where, $X_{\mathrm{r} i}$ and $X_{\mathrm{w} i}$ represent the rating and the weight assigned to a parameter $X$, respectively, in $i$ th sub-area and $V_{i}$ is the vulnerability index as mentioned above. The sensitivity analysis helps to validate and evaluate the consistency of the analytical results and is the basis for proper evaluation of vulnerability maps. A more efficient interpretation of the vulnerability index can be achieved through sensitivity analysis. The summary of the results of sensitivity analysis that was performed by removing one or more data layer is represented in Tables 4 and 5. Statistical analysis results (shown in Table 4) indicate that the most sensitive to groundwater pollution is the parameter $D$, followed in importance by factors $R, I, A, C, S$ and $T$. The highest mean value was associated with the depth to groundwater table (4.52) whereas the impact of vadose zone shows the lowest sensitive value (0.32). The results of variation index (shown in Table 5) clearly indicate that the parameter $R$ has the highest variation index (0.274) followed by parameter I of variation index (0.234). This

Table 4 Statistics of single parameter sensitivity analysis

\begin{tabular}{lllll}
\hline Parameter & $\begin{array}{l}\text { Minimum } \\
\text { value }\end{array}$ & $\begin{array}{l}\text { Maximum } \\
\text { value }\end{array}$ & Mean & $\begin{array}{l}\text { Standard } \\
\text { deviation }\end{array}$ \\
\hline$D$ & 3.47 & 5.71 & 4.52 & 0.35 \\
$R$ & 0.45 & 3.11 & 2.71 & 0.42 \\
$A$ & 0 & 1.57 & 1.09 & 0.27 \\
$S$ & 1.21 & 3.02 & 1.98 & 0.19 \\
$T$ & 1 & 3.92 & 2.67 & 0.23 \\
$I$ & 0 & 1.52 & 0.32 & 0.28 \\
$C$ & 0.45 & 2.92 & 1.33 & 0.47 \\
\hline
\end{tabular}

variation index explains the effect on vulnerability index on removal of any parameter.

Variation index is directly associated with the weighting system of the model. New or effective weights for each input parameters were computed using the Eqs. (3) and (4) and reported in Table 5. The effective weight factor results clearly indicate that the parameter $D$ dominates the vulnerability index with an average weight of $23.84 \%$ against the theoretical weight of $21.74 \%$. The actual weight of parameter $I(16.77 \%)$ is smaller than the theoretical weight (21.74). The calculated weight of parameter $T(7.07 \%)$ is greater than theoretical weight $(4.35 \%)$. The highest effective weight of parameter $D$ clearly indicates the presence of shallow groundwater table in the most part of the study area and the calculated effective weight of parameter $T$ is more than theoretical weight due to the fact that the slope in most of the part of the study area is $<6 \%$.

It is clearly observed in the study that the calculated effective weights for each parameter are not equal to the theoretical weight assigned in DRASTIC method. This is due to the fact that weight factors are strongly related to the value of a single parameter in the context of value chosen for the other parameters. Therefore, the determination of effective weights is very useful to revise the weight factors assigned in DRASTIC method and may be applied more scientifically to address the local issues.

\section{Conclusions}

A GIS-based DRASTIC model was used for computing the groundwater vulnerability to pollution index map of Ranchi district. The study area was divided into five zones (low, moderately low moderate, moderately high and high) on the basis of relative groundwater vulnerability to pollution index. Higher the value of the vulnerability index, higher is the risk of groundwater contamination. The results reveal that moderate vulnerable class covers the maximum percentage of the area $(38.85 \%$ of the total area). Moderately high vulnerability class and moderately

Table 5 Assigned weights and effective weights

\begin{tabular}{llllll}
\hline Parameter & $\begin{array}{l}\text { Assigned } \\
\text { weight }\end{array}$ & $\begin{array}{l}\text { Assigned } \\
\text { weight }(\%)\end{array}$ & $\begin{array}{l}\text { Variation } \\
\text { index }\left(W_{\mathrm{x} i}\right)\end{array}$ & $\begin{array}{l}\text { Calculated effective } \\
\text { weight after rescaling }\left(X_{\mathrm{w} i}\right)\end{array}$ & $\begin{array}{l}\text { Calculated effective } \\
\text { weight }(\%)\end{array}$ \\
\hline$D$ & 5 & 21.74 & $0.26-0.46$ & $6.09-10.65$ & $26.47-46.3$ \\
$R$ & 4 & 17.39 & $0.08-0.29$ & $1.89-6.73$ & $8.21-29.27$ \\
$A$ & 3 & 13.04 & $0.08-0.19$ & $1.84-4.5$ & $8-19.57$ \\
$S$ & 2 & 8.69 & $0.03-0.08$ & $0.79-1.8$ & $3.42-7.84$ \\
$T$ & 1 & 4.35 & $0.03-0.08$ & $0.72-1.85$ & $-3.14-8.06$ \\
$I$ & 5 & 21.74 & $0.09-0.22$ & $2.06-5.13$ & $8.98-22.32$ \\
$C$ & 3 & 13.04 & $0.02-0.22$ & $0.47-5.0$ & $2.06-21.74$ \\
\hline
\end{tabular}


low vulnerability class also cover significant share of the area.

Sensitivity analysis results indicate that the new effective weights for each parameter are not equal to the theoretical weight assigned in DRASTIC method. Thus, the computation of effective weights is very useful to revise the weight factors assigned in DRASTIC method and may be applied more scientifically to address the local issues.

Groundwater has an important role in drinking water supply in Ranchi district. The study suggests that the GISbased DRASTIC model can be used for identification of the vulnerable areas for groundwater quality management. In the vulnerable areas, detailed and frequent monitoring of groundwater should be carried out for observing the changing level of pollutants. Furthermore, the present study also helps for screening the site selection for waste dumping.

Acknowledgments The authors are thankful to the University Grants Commission (UGC), New Delhi for providing financial support [F.N.39-965/2010 (SR)] which made this study possible. The support of the JSAC, Ranchi, CGWB, New Delhi, and BAU, Ranchi is acknowledged for providing some data. The authors are also thankful to the anonymous reviewers and editors to make the paper more presentable and good.

Open Access This article is distributed under the terms of the Creative Commons Attribution License which permits any use, distribution, and reproduction in any medium, provided the original author(s) and the source are credited.

\section{References}

Al-Adamat RAN, Foster IDL, Baban SMJ (2003) Groundwater vulnerability and risk mapping for the basaltic aquifer of the Azraq basin of Jordan using GIS, remote sensing and DRASTIC. Appl Geogr 23:303-324

Aller L, Bennett T, Lehr JH, Petty RJ (1987) DRASTIC: a standardized system for evaluating groundwater pollution potential using hydrogeologic settings. USEPA, Robert S. Kerr Environmental Research Laboratory, Ada, OK. EPA/600/2 $85 / 0108$

Almasri Mohammad N (2008) Assessment of intrinsic vulnerability to contamination for Gaza coastal aquifer, Palestine. J Environ Manag 88:577-593

Aminreza Neshat, Pradhan B, Pirasteh S, Shafri HZM (2014) Estimating groundwater vulnerability to pollution using a modified DRASTIC model in the Kerman agricultural area, Iran. Environ Earth Sci 71:3119-3131

Anwar MC, Prem, Rao VB (2003) Evaluation of groundwater potential of Musi River catchment using DRASTIC index model. In: Venkateshwar B R, Ram MK, Sarala C S, Raju C (eds) Hydrology and watershed management. Proceedings of the International Conference 18-20, 2002, B S Publishers, Hyderabad

APHA Standard Methods (1995) Standard methods for the examination of water and wastewater. In: Andrew D Eaton, Lenore S Clesceri, Arnold E Greenberg (eds) American Public Health Association (APHA), 19th edition, Washington
Babiker IS, Mohamed AAM, Hiyama T, Kato K (2005) A GIS-based DRASTIC model for assessing aquifer vulnerability in Kakamigahara Heights, Gifu Prefecture, Central Japan. Sci Total Environ 345(1-3):127-140

Barbash JE, Resek EA (1996) Pesticides in groundwater: distribution, trends, and governing factors. Pesticides in the hydrologic system series, vol 2. Ann Arbor Press, Chelsea, Michigan, p 590

Berkhoff K (2008) Spatially explicit groundwater vulnerability assessment to support the implementation of the Water Framework Directive-a practical approach with stakeholders. Hydrol Earth Syst Sci 12:111-122

Burkart MR, Feher J (1996) Regional estimation of groundwater vulnerability to non-point sources of agricultural chemicals. Water Sci Technol 33:241-247

Central Ground Water Board (CGWB) (2009) Groundwater information booklet. Available on http://cgwb.gov.in/District_Profile/ Jharkhand/RANCHI.pdf. Accessed 15th Dec 2012

Chae G, Kim K, Yun S, Kim K, Kim S, Choi B, Kim H, Rhee CW (2004) Hydrogeochemistry of alluvial groundwater in an agricultural area: an implication for groundwater contamination susceptibility. Chemosphere 55:369-378

Chandrashekhar H, Adiga S, Lakshminarayana V, Jagdeesha CJ, Nataraju C (1999) A case study using the model 'DRASTIC' for assessment of groundwater pollution potential. In Proceedings of the ISRS national symposium on remote sensing applications for natural resources, June 19-21, Bangalore

Civita MV (1994) "Le carte della vulnerabilità degli acquiferi all'inquinamento: Teoria \& pratica," (Groundwater vulnerability maps to contamination: Theory and practice) Pitagora Editrice, Bologna, pp. 325 (with bibliography)

Connell LD, Daele G (2003) A quantitative approach to aquifer vulnerability mapping. J Hydrol 276:71-88

Dixon B (2005) Groundwater vulnerability mapping: a GIS and fuzzy rule based integrated tool. Appl Geogr 25:327-347

Ferreira Lobo JP, Oliveira Manuel M (2004) Groundwater vulnerability assessment in Portugal. Geofis Int 43(4):541-550

Fobe B, Goossens M (1990) The groundwater vulnerability map for the Flemish region: its principles and uses. Eng Geol 29:355-363

Foster SSD (1987) Fundamental concepts in aquifer vulnerability, pollution risk and protection strategy. In: van Duijvenbooden, W, van Waegeningh GH (eds) TNO Committee on Hydrological Research, the Hague, Proceedings and Information, 38:69-86

Giambelluca TW, Loague K, Green RE, Nullet MA (1996) Uncertainty in recharge estimation: impact on groundwater vulnerability assessments for the Pearl Harbor Basin, O'ahu, Hawai'i, USA. J Contam Hydrol 23:85-112

Gogu RC, Dassargues A (2000a) Sensitivity analysis for the EPIK method of vulnerability assessment in a small karstic aquifer, Southern Belgium. Hydrogeol J 8(3):337-345

Gogu RC, Dassargues A (2000b) Current trends and future challenges in groundwater vulnerability assessment using overlay and index methods. Environ Geol 39:549-559

Herlinger R Jr, Viero AP (2007) Groundwater vulnerability assessment in coastal plain of Rio Grande do Sul State, Brazil, using drastic and adsorption capacity of soils. Environ Geol 52:819-829

Karolin Brosig, Geyer T, Subah A, Sauter M (2008) Travel time based approach for the assessment of vulnerability of karst groundwater: the Transit Time Method. Environ Geol 54:905-911

Kim YJ, Hamm S (1999) Assessment of the potential for groundwater contamination using the DRASTIC/EGIS technique, Cheongju area, South Korea. Hydrogeol J 7:227-235

Kwansiririkul K, Singharajwarapan FS, Mackay R, Ramingwong T, Wongpornchai P (2004) Vulnerability assessment of groundwater resources in the Lampang Basin of Northern Thailand. J Environ Hydrol 12(23):1-15 
Lake IR, Lovett AA, Hiscock KM, Betson M, Foley A, Sunnenberg G, Evers S, Fletcher S (2003) Evaluating factors influencing groundwater vulnerability to nitrate pollution: developing the potential of GIS. J Environ Manag 68:315-328

Lodwik WA, Monson W, Svoboda L (1990) Attribute error and sensitivity analysis of maps operation in geographical information systems: suitability analysis. Int J Geogr Inf Syst 4:413-428

Margat J (1968) Groundwater vulnerability to contamination. 68, BRGM, Orleans, France. In: Massone et. al. 2010, Enhanced groundwater vulnerability assessment in geological homogeneous areas: a case study from the Argentine Pampas. Hydrogeol J 18: 371-379

Massone H, Londoño MQ, Martínez D (2010) Enhanced groundwater vulnerability assessment in geological homogeneous areas: a case study from the Argentine Pampas. Hydrogeol J 18:371-379

Merchant JW (1994) GIS-based groundwater pollution hazard assessment: a critical review of the DRASTIC model. Photogramm Eng Rem S 60(9):1117-1127

Napolitano P, Fabbri AG (1996) Single parameter sensitivity analysis for aquifer vulnerability assessment using DRASTIC and SINTACS. In: Proceedings of the 2nd HydroGIS Conference, vol. 235. IAHS Publication, Wallingford, pp 559-566

National Research Council (NRC) (1993) Groundwater vulnerability assessment: predicting relative contamination potential under conditions of uncertainty. National Academy Press, Washington

Nouri J, Malmasi S (2005) The role of groundwater vulnerability in urban development planning. Am J Environ Sci 1:16-21

Polemio M, Casarano D, Limoni PP (2009) Karstic aquifer vulnerability assessment methods and results at a test site (Apulia, southern Italy). Nat Hazards Earth Syst Sci 9:1461-1470

Rahman A (2008) A GIS based DRASTIC model for assessing groundwater vulnerability in shallow aquifer in Aligarh, India. Appl Geogr 28:32-53

Rational formula for runoff coefficient. Available on http://water.me. vccs.edu/courses/CIV246/table2b.htm. Accessed 02nd March 2014

Rupert MG (2001) Calibration of the DRASTIC groundwater vulnerability mapping method. Ground Water 39:630-635

Secunda S, Collin M, Mellou AJ (1998) Groundwater vulnerability assessment using a composite model combining DRASTIC with extensive land use in Israel. J Environ Manag 54:39-57
Shirazi SM, Imran MH, Akib S (2012) GIS based DRASTIC method for groundwater vulnerability assessment: a review. J Risk Res 15:991-1011

Shirazi SM, Imran MH, Akib S, Yusop Z, Harun ZB (2013) Groundwater vulnerability assessment in Melaka state of Malaysia using DRASTIC and GIS techniques. Environ Earth Sci 70:2293-2304

Sinan M, Razack M (2009) An extension to the DRASTIC model to assess groundwater vulnerability to pollution: application to the Haouz aquifer of Marrakech (Morocco). Environ Geol 57:349-363

Soutter M, Musy A (1998) Coupling 1D Monte-Carlo simulations and geostatistics to assess groundwater vulnerability to pesticide contamination on a regional scale. J Contam Hydrol 32:25-39

Tesoriero AJ, Inkpen EL, Voss FD (1998) Assessing groundwater vulnerability using logistic regression. Proceedings for the Source Water Assessment and Protection 98 Conference, Dallas, TX, 157-165

Thapinta A, Hudak P (2003) Use of geographic information systems for assessing groundwater pollution potential by pesticides in Central Thailand. Environ Int 29:87-93

Vias JM, Andreo B, Perles MJ, Carrasco F (2005) A comparative study of four schemes for groundwater vulnerability mapping in a diffuse flow carbonate aquifer under Mediterranean climatic conditions. Environ Geol 47:586-595

Villeneuve JP, Banton O, Lafrance P (1990) A probabilistic approach for the groundwater vulnerability to contamination by pesticides: the VULPEST model. Ecol Model 51:47-58

Vrba J, Zaporozec A (1994) Guidebook on mapping groundwater vulnerability. Int. Association of Hydrogeologists. Int. Contributions to Hydrogeology; 16. Verlag Heinz Heise, Hannover

Worrall F, Besien T (2004) The vulnerability of groundwater to pesticide contamination estimated directly from observations of presence or absence in wells. J Hydrol 303:92-107

Worrall F, Besien T, Kolpin DD (2002) Groundwater vulnerability: interactions of chemical and site properties. Sci Total Environ 299:131-143

Zektser IS, Karimova OA, Bujuoli J, Bucci M (2004) Regional estimation of fresh groundwater vulnerability: methodological aspects and practical applications. Water Resour 31:645-650

Zhang R, Hamerlinck JD, Gloss SP, Munn L (1996) Determination of nonpoint-source pollution using GIS and numerical models. J Environ Qual 25(3):411-418 